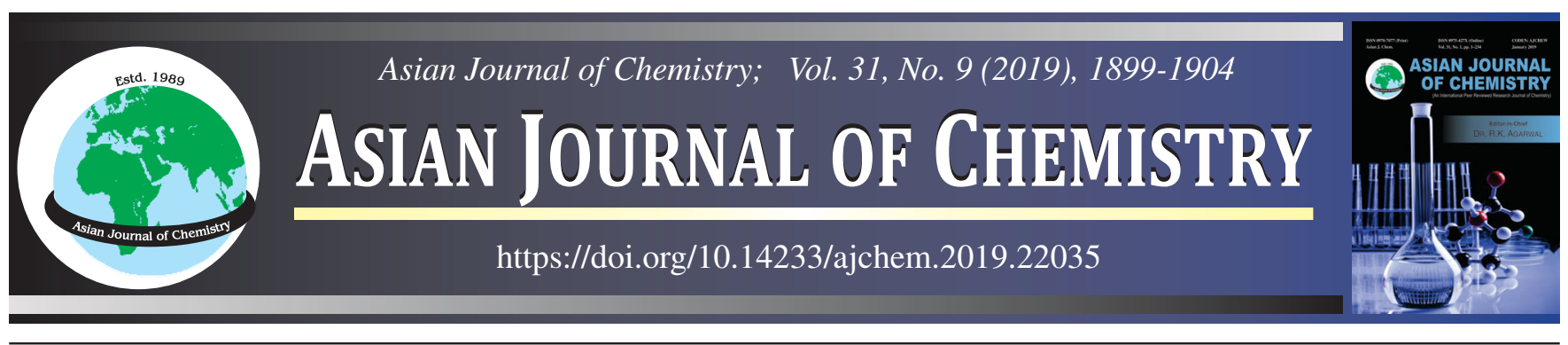

\title{
Anticancer Activity of Copper Oxide Nanoparticles Synthesized from Brassia actinophylla Flower Extract
}

\author{
K. Subashini ${ }^{1,2}$, S. Prakash ${ }^{1}$ and V. Sujatha ${ }^{1, *}$
}

${ }^{1}$ Department of Chemistry, Periyar University, Salem-636011, India

${ }^{2}$ Department of Chemistry, New Horizon College of Engineering, Bangalore-560103, India

*Corresponding author: E-mail: chemsujatha888@gmail.com

Received: 27 February 2019;

Accepted: 26 March 2019;

Published online: 31 July 2019;

AJC-19474

\begin{abstract}
There are many methods to synthesize metal and metal oxide nanoparticles. In this paper, copper oxide nanoparticles have been synthesized by solution combustion method using Brassia actinophylla i.e. Schefflera actinophylla flower extract belongs to Araliaceae family. The importance of solution combustion is one of the easy and simplest methods for the synthesis of metal oxide nanoparticle. The CuO nanoparticles were synthesized at various temperatures and the characterization has been carried out by UV, FTIR, PXRD, SEM, TEM and EDAX analysis. At lower temperature, the peak was not observed but at $400{ }^{\circ} \mathrm{C}$, the UV peak was observed at $340 \mathrm{~nm}$. The FTIR peaks observed at $1000-500 \mathrm{~cm}^{-1}$ confirms again the presence of $\mathrm{CuO}$ nanoparticles. The monoclinic phase and crystalline structure of nanoparticles were revealed by PXRD pattern, by Scherrer's method the average crystalline sizes were found to be in the range of 15 to 24 $\mathrm{nm}$. The size and the shape of nanoparticles were confirmed by SEM and TEM reports. The SEM images of nanoparticles show spherical in shape and free from agglomeration. TEM analysis reports the nanoparticle sizes ranging from 2 to $20 \mathrm{~nm}$. The percentage of copper (52 $\%)$ and oxygen $(26 \%)$ elements were recorded in the EDAX analysis. The study of size and stability of nanoparticles were done by zeta potential values. The antibacterial activity of $\mathrm{CuO}$ nanoparticles were carried out against Staphylococcus aureus and Escherichia coli bacteria's by agar well diffusion method. The MTT assay was performed in order to check the anticancer activity of CuO nanoparticles against HT-29 colon cancer cells.
\end{abstract}

Keywords: Brassia actinophylla, $\mathrm{CuO}$ nanoparticles, Anticancer activity, Zeta potential.

ᄂ -

\section{INTRODUCTION}

There are different methods to prepare nanoparticles such as physical, chemical and biological methods [1-4]. It is difficult to achieve the controlled size and stability of nanoparticles by chemical reduction method, but the green synthesis of nanoparticles using plant extracts is friendly to nature and inexpensive [5-7]. The green synthesis of nanoparticles process involves various parts of the medicinal plants as reducing agents. The extracts prepared from leaves, steam, roots, flowers and the seeds of medicinal plants were employed as a reducing agent for the nanoparticle synthesis. Nanoparticles like copper, zinc, silver and their oxides $(\mathrm{CuO}, \mathrm{ZnO}$ and $\mathrm{AgO})$ were synthesized by using above method [8]. The nanoparticles synthesized by green synthesis method is stable. The reducing agent used in chemical method such as sodium borohydride and hydrazine causes skin, eye, nose and throat irritation. The toxic chemicals released during chemical synthesis of nanoparticles causes difficulties to all the living things and environment. The more usage of above chemicals affects the nervous system [9]. The pulse laser ablation, microwave-assisted and pulsed /explosion wire discharge methods are physical methods to synthesize nanoparticles. The efficiency of the laser method is less but its high cost and high energy consumption method [10]. The radiations produced in microwave assisted synthesis are hazards to health. The pulsed/explosion wire discharge method has some contaminations in the final product [11]. Because of the above impulsion, medicinal plant extracts are put to use to synthesize nanoparticles. Now a days many nanoparticles were synthesized using plants such as neem [12], Cinnamomum camphora [13], lemon grass [14], tamarind [15] and Euphorbia tirucalli [16]. Metal oxides mainly $\mathrm{CuO}$ nanoparticles have

This is an open access journal, and articles are distributed under the terms of the Attribution 4.0 International (CC BY 4.0) License. This license lets others distribute, remix, tweak, and build upon your work, even commercially, as long as they credit the author for the original creation. You must give appropriate credit, provide a link to the license, and indicate if changes were made. 
various applications like catalytic [17], electrical [18], optical [19] and superconductors [20]. The optical and electrical properties are highly beneficial to produce multipurpose nano-sized electronic and opto electronic devices [21-23]. The band gap of $\mathrm{CuO}$ nanoparticles is $1.2 \mathrm{eV}$ and these nanoparticles are p-type semiconductors, used in industries such as gas sensing, solar energy conversion, magnetic storage media, field emission devices and batteries [24]. $\mathrm{CuO}$ nanoparticles have variety of biological activities including antibacterial, anticancer, antidiabetic, anti-inflammatory, antioxidant and wound healing [25-27].

Brassia actinophylla is also called as Schefflera actinophylla [28]. The leaves forming umbrella-like symmetrical heads so it is named as Umbrella tree. It grows up to 100 feet. The phenolic and flavonoid compounds are present in this plant shows antioxidant activity [29]. There are several routes to prepare $\mathrm{CuO}$ nanoparticles, namely microwave irradiations [30], thermal decomposition [31], sol-gel [32] and solid-state reaction method [33]. In a simple and easiest way, metal oxides can be prepared by solution combustion method [34]. Herein, $\mathrm{CuO}$ nanoparticles were prepared using Brassia actinophylla flower extract by solution combustion method. The synthesized $\mathrm{CuO}$ nanoparticles were mainly taken for the antibacterial activity against Gram positive and Gram negative bacteria's. The $\mathrm{CuO}$ nanoparticles were checked for the anticancer activity using HT-29 colon cancer cells.

\section{EXPERIMENTAL}

Cupric nitrate hexahydrate $\left[\mathrm{Cu}\left(\mathrm{NO}_{3}\right)_{2} \cdot 6 \mathrm{H}_{2} \mathrm{O}\right] 98 \%$ pure was purchased from Fischer-Scientific, India. The plant was collected from New Horizon College Campus, Bangalore, India and authenticated by Institute of Trans-Disciplinary Health Sciences and Technology, Yelahanka, India. Scientific classification of plant is Plantae Kingdom, Apiales Order, Araliaceae Family, Schefflera genus, S. actinophylla species and binomial name is Schefflera acinophylla, Synonyms: Brassia actinophylla.

The UV-visible spectrum of synthesized $\mathrm{CuO}$ nanoparticles were measured by UV-2301 (Techcom) spectrometer. FTIR spectrum was recorded for evaluate the organic and inorganic constituents in wavelength ranging from 4000-500 $\mathrm{cm}^{-1}$ through Nicolet iS5 FTIR Spectrometer (Thermo Fisher). EDAX and PXRD analysis were carried out by X-ray diffractometers (PANalytical) instrument. Morphology study of green synthesized nanoparticles was carried out from SEM (TESCANVEGA3) analysis. Size and morphological analysis of nanoparticles were done by TEM (Jeol/JEM2100) instrument. Further, stability of green synthesized nanoparticles was determined by zeta potential analysis.

Preparation of plant extract: Brassia actinophylla flowers were collected and dried under the absence of sunlight condition, after that it was grained to powder form and taken for extraction process using Soxhelt apparatus around $70 \mathrm{~h}$ at $45-60^{\circ} \mathrm{C}$. The aqueous solution was subjected to concentrate by using rotary flash evaporator (Buchi, Flawil, Switzerland) at $40 \pm 5^{\circ} \mathrm{C}$ under reduced pressure. Then concentrated extract was dried in hot air oven at $50-60{ }^{\circ} \mathrm{C}$, eventually the dried crude extract was utilized for the synthesis of nanoparticles.
Synthesis of $\mathrm{CuO}$ nanoparticles: To synthesize $\mathrm{CuO}$ nanoparticles, $0.21 \mathrm{~g}$ of dried crude flower extract of B. actinophylla and stoichiometric amount of cupric nitrate hexahydrate was dissolved in $10 \mathrm{~mL}$ of distilled water with constant stirring about 10-15 min to attain the homogeneous condition and the mixture solution was kept in a pre-heated in muffle furnace maintained at $100 \pm 10^{\circ} \mathrm{C}$ for $10-12 \mathrm{~min}$. And the above condition was repeated and calcinated for various temperatures $\left(200^{\circ} \mathrm{C}\right.$ and $400^{\circ} \mathrm{C}$ ). The black coloured powder materials were obtained and cooled to room temperature afterwards stored it in airtight container for further studies [35].

Antibacterial activity: The agar well diffusion method has been employed to notice the antibacterial activity against Staphylococcus aureus (Gram +ve) and Escherichia coli (Gram -ve) for the synthesized $\mathrm{CuO}$ nanoparticles [36,37]. Then wells were prepared in the plates with a cork borer. Each well was loaded with various concentration of samples such as 300,450 , $600,750,900 \mu \mathrm{g} / \mathrm{mL}$. For positive control, $10 \mathrm{mg}$ of tetracycline dissolved in $1 \mathrm{~mL}$ of $10 \%$ DMSO was used. The plates were incubated for $24 \mathrm{~h}$ by maintaining the temperature at $37^{\circ} \mathrm{C}$.

Anticancer activity: The log phase colon cancer cells (HT29) were suspended in the complete DMEM media to make a final cell concentration of $4 \times 10^{3} / \mathrm{mL}$ cells. In a tissue-culture coated 96-well plate, $150 \mu \mathrm{g}$ of these cells were seeded and incubated at $37^{\circ} \mathrm{C}$ overnight supplemented with $5 \% \mathrm{CO}_{2}$. After that, when cells were adhered to plate surface, the given samples was supplemented at different concentration to make the final volume of $200 \mu \mathrm{g}$. The concentrations used were 20, $40,60,80$ and $100 \mu \mathrm{g} / \mathrm{mL}$. All the concentrations were added as triplicates along with control i.e. media without cells and cells without test samples. After $24 \mathrm{~h}, 20 \mu \mathrm{g}$ of MTT solution $(5 \mathrm{mg} / \mathrm{mL}$ in PBS) was added to each well and incubated for $4 \mathrm{~h}$ at $37^{\circ} \mathrm{C}$. Then, $100 \mu \mathrm{g}$ of DMSO (to solubilize the purple formazon) was added, incubated for $0.5 \mathrm{~h}$, after which the absorbance at $570 \mathrm{~nm}$ was recorded with a microplate reader (Thermoscientific Multiskan FC) [38,39]. Growth cancer cells were expressed as the percentage of cell viability.

\section{RESULTS AND DISCUSSION}

UV-visible analysis: The formation of green synthesized $\mathrm{CuO}$ nanoparticles were monitored by $\mathrm{UV}$-visible spectrum at various temperatures such as 100, 200 and $400{ }^{\circ} \mathrm{C}$ (Fig. 1). Initially at $100^{\circ} \mathrm{C}$, there is no absorption peak appeared which indicates the absence of nanoparticle formation. Subsequently at $200^{\circ} \mathrm{C}$ also did not exhibit any peaks in spectrum. Because decomposition of organic material was not completely carried out therefore no absorption peak arises for nanoparticles formation. While at $400{ }^{\circ} \mathrm{C}$ calcination, fine black colour power was obtained and subjected UV-visible spectrum has revealed a peak at $340 \mathrm{~nm}$ which confirmed the formation of $\mathrm{CuO}$ nanoparticles [40].

FT-IR analysis: Formation of the green synthesized $\mathrm{CuO}$ nanoparticles were confirmed by FT-IR analysis. FT-IR analysis of $100{ }^{\circ} \mathrm{C}$ calcinated material has revealed different vibration peaks like $2913 \mathrm{~cm}^{-1}$, which is due to $\mathrm{C}-\mathrm{H}$ stretching vibration, the band at $2359 \mathrm{~cm}^{-1}$ shows the $\mathrm{O}=\mathrm{C}=\mathrm{O}$ vibration, $1386 \mathrm{~cm}^{-1}$ for bending vibration of methyl bending and $1032 \mathrm{~cm}^{-1}$ indicates 

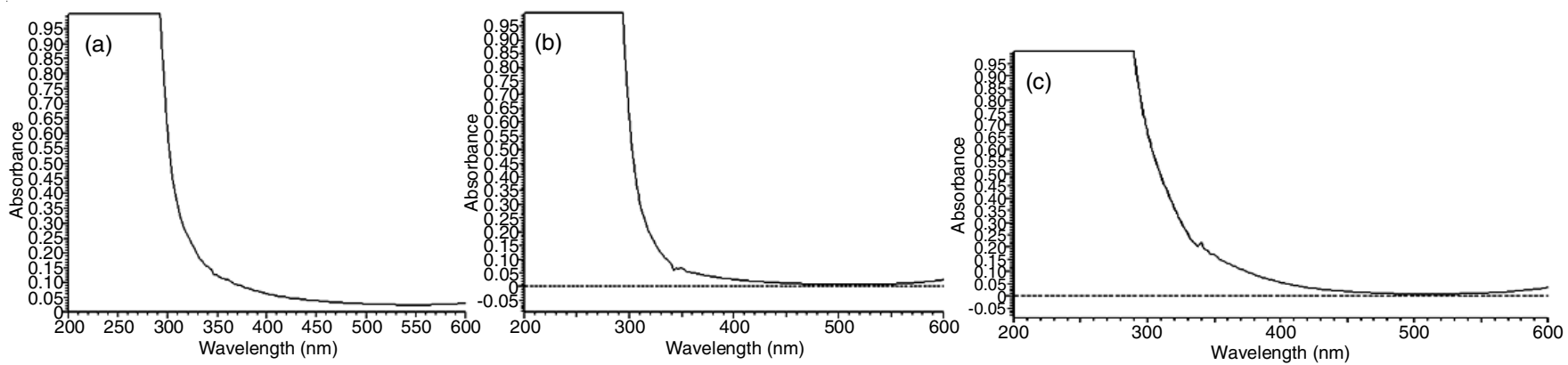

Fig. 1. (a-c) UV-visible spectrum of green synthesized $\mathrm{CuO}$ nanoparticles at various temperature of combustion from Brassia actinophylla flower extract

the -C-O stretching vibration. At $200^{\circ} \mathrm{C}$ calci-nation, FT-IR analysis exhibited $3446 \mathrm{~cm}^{-1}$ peak for C-H stretching and 2917 $\mathrm{cm}^{-1}$ for aliphatic $\mathrm{C}-\mathrm{H}$ stretching. A sharp peak at $2359 \mathrm{~cm}^{-1}$ shows the $\mathrm{O}=\mathrm{C}=\mathrm{O}$ bending vibration. The peaks at 1653,1636 , $1558 \mathrm{~cm}^{-1}$ represented the $-\mathrm{C}=\mathrm{O}$ stretching and $1025 \mathrm{~cm}^{-1}$ peak observed for $-\mathrm{C}-\mathrm{O}$ stretching. However, at $400{ }^{\circ} \mathrm{C}$ calcinated material of green synthesis has revealed the sharp peaks at $537 \mathrm{~cm}^{-1}$ in spectrum (Fig. 2), which indi-cates the metal oxygen (M-O) vibration [41]. And along with above observed peaks of organic compounds were also detected in $400{ }^{\circ} \mathrm{C}$ calcinated material, which portrayed the plant active compounds are involved in the nanoparticles synthesis. The FT-IR analysis exhibited the metal oxygen vibration peak (537 $\mathrm{cm}^{-1}$ ) in $400{ }^{\circ} \mathrm{C}$ calcinated green synthesized material only. Hence the results of UV-Visible spectrum and FT-IR spectrum analysis confirmed the formation of $\mathrm{CuO}$ nanoparticles was achieved in $400{ }^{\circ} \mathrm{C}$ calcination.

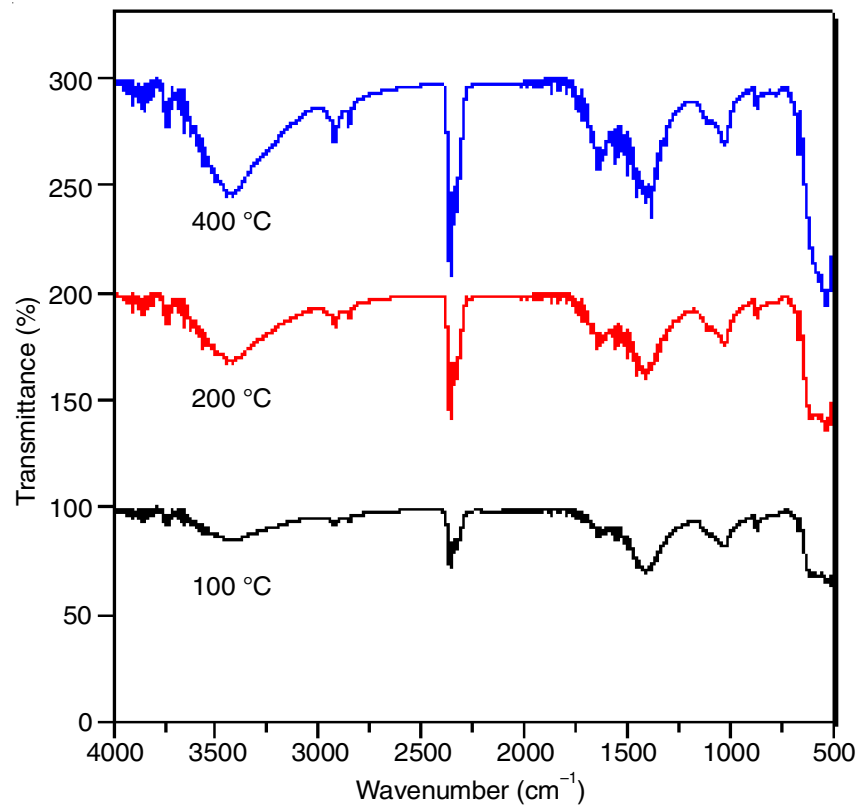

Fig. 2. FT-IR analysis of green synthesized $\mathrm{CuO}$ nanoparticles Brassia actinophylla flower extract

PXRD and EDAX analysis: The synthesized $\mathrm{CuO}$ nanoparticles were subjected to explore its crystalline properties by powder XRD analysis (Fig. 3). The peaks were observed in phase like 002 (111), 111(200), $(\overline{2} 02,020,202,113$. The brodended peak indicates the size of the particles were small and monoclinic. However, the XRD peaks are well matched

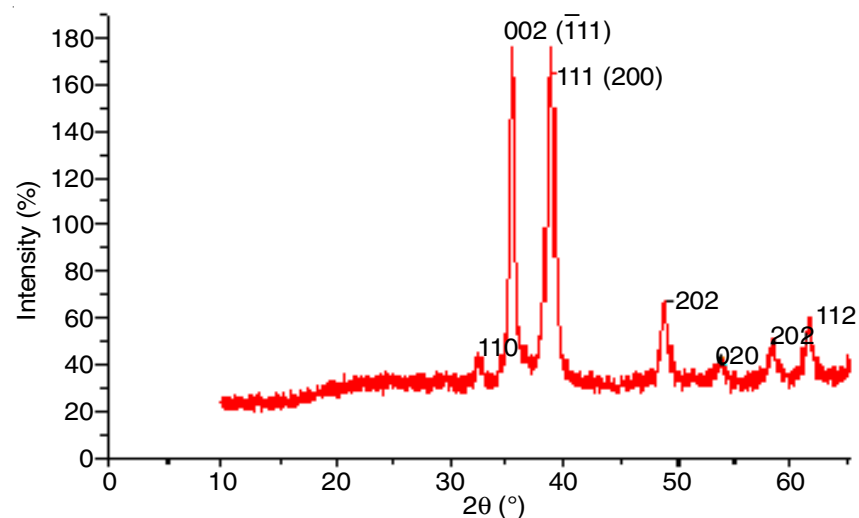

Fig. 3. Powder XRD analysis of green synthesizd $\mathrm{CuO}$ nanoparticles Brassia actinophylla flower extract

with standard of Joint Committee on Powder Diffraction data (JCPD Card no: 05-0661). The less number of impurity peaks of $\mathrm{CuO}$ nanoparticles were observed in XRD pattern indicates the high phase purity.

Debye-Scherrer's formula $D=k \lambda / \beta \cos \theta$ used to calculate the average crystalline size [42]; where $\mathrm{k}$ is equal to $0.94, \lambda$ is the wavelength of X-ray radiation (1.5406 $\AA$ ), $\beta$ is the fullwidth at half maximum (FWHM) and $2 \theta$ is the Bragg angle (in degree). The average crystallize size of green synthesized $\mathrm{CuO}$ nanoparticles found to be in the range of 15 to $24 \mathrm{~nm}$. The diffraction peaks were recorded at $35.6^{\circ}, 38.9^{\circ}, 49^{\circ}, 61.8^{\circ}$, $66.27^{\circ}$ angles which corresponds to the lattice (002) (111), (111) (200), (202) (020), (113).

The EDAX analysis exhibited the presence of elements composition in green synthesized $\mathrm{CuO}$ nanoparticles using aqueous extract of Brassia actinophylla flower . In synthesized nanoparticles, copper element was recorded as $52 \%$ and oxygen recorded as $26 \%$. Besides other elements such as carbon (19\%) and potassium ( $2 \%$ ) was recorded as insignificantly (Fig. 4).

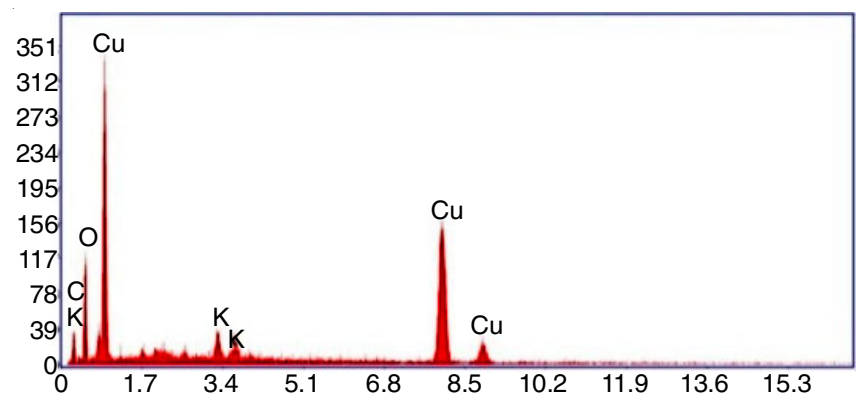

Fig. 4. EDAX analysis of green synthesized $\mathrm{CuO}$ nanoparticles from Brassia actinophylla flower extract 
SEM analysis: The morphology of synthesized $\mathrm{CuO}$ nanoparticles were investigated by SEM analysis. The SEM image (Fig. 5a) at $10 \mu \mathrm{m}$ magnification shows the nanoparticles as pores material, due to liberation of organic and gaseous molecules. In higher magnification at $500 \mathrm{~nm}$ has revealed the synthesized $\mathrm{CuO}$ nanoparticles are sperical in shape and having less agglomeration (Fig. 5b). However, more or less same morpological observation was noted in earilier report for synthesis of $\mathrm{CuO}$ nanoparticles using aqueous extract of Gloriosa superba L. leave [43].

TEM analysis: The exact size and morphological appearance of Brassia actinophylla flower aqueous extract mediated green synthesized $\mathrm{CuO}$ nanoparticles were examined by TEM analysis. The synthesized $\mathrm{CuO}$ nanoparticles shown in Fig. 6a are spherical in shape and the particles having less aggregation. The size of $\mathrm{CuO}$ nanoparticles were observed in range of 2-20 $\mathrm{nm}$. Characteristics of nanoparticles varied by its size. If nanoparticles having very small size then it will have higher surface area and high reactive sites, thus nanoparticles has been studied widely because they possess more interaction and permeability within the cell wall metabolites of living things [44]. Hence, the size of synthesized nanoparticles has much concentraction to furnish effectiveness biological applications of it. The SEAD pattern of synthesized $\mathrm{CuO}$ nanoparticles (Fig. 6b) comfirms the nanoparticles are in crystallite nature.

Zeta potential: Zeta potential analysis has been widely used to examine the stability of nanoparticles in a disperesed medium. Nanoparticles with a zeta potential between -10 to $+10 \mathrm{mV}$ are cosidered approximately neutral and increases considered as moderately stable. If zeta potentials values of the nanoparticles are greater than $+30 \mathrm{mV}$ or less than $-30 \mathrm{mV}$ are considered as highly stable [45]. In this process, synthesized $\mathrm{CuO}$ nanoparticles zeta potential were detected as -13.2 $\mathrm{mV}$ (Fig. 7). The zeta potential value of Brassia actinophylla flower aqueous mediated synthesized $\mathrm{CuO}$ nanoparticles ensure the nanoparticles possesse moderate stability.

Anticancer activity: The biological application of Brassia actinophylla aqueous flower extract mediated synthesized $\mathrm{CuO}$ nanoparticles was evaluated by in vitro anticancer activity against colon cancer HT-29 cell line. The cancer cell living time and its proliferation have been examined by MTT assay based on the reduction of tetrazolium salt. In the present study, the synthesized $\mathrm{CuO}$ nanoparticles were taken in various concentration like 20, 40, 60, 80 and $100 \mu \mathrm{g} / \mathrm{mL}$ (Fig. 8). The percen-
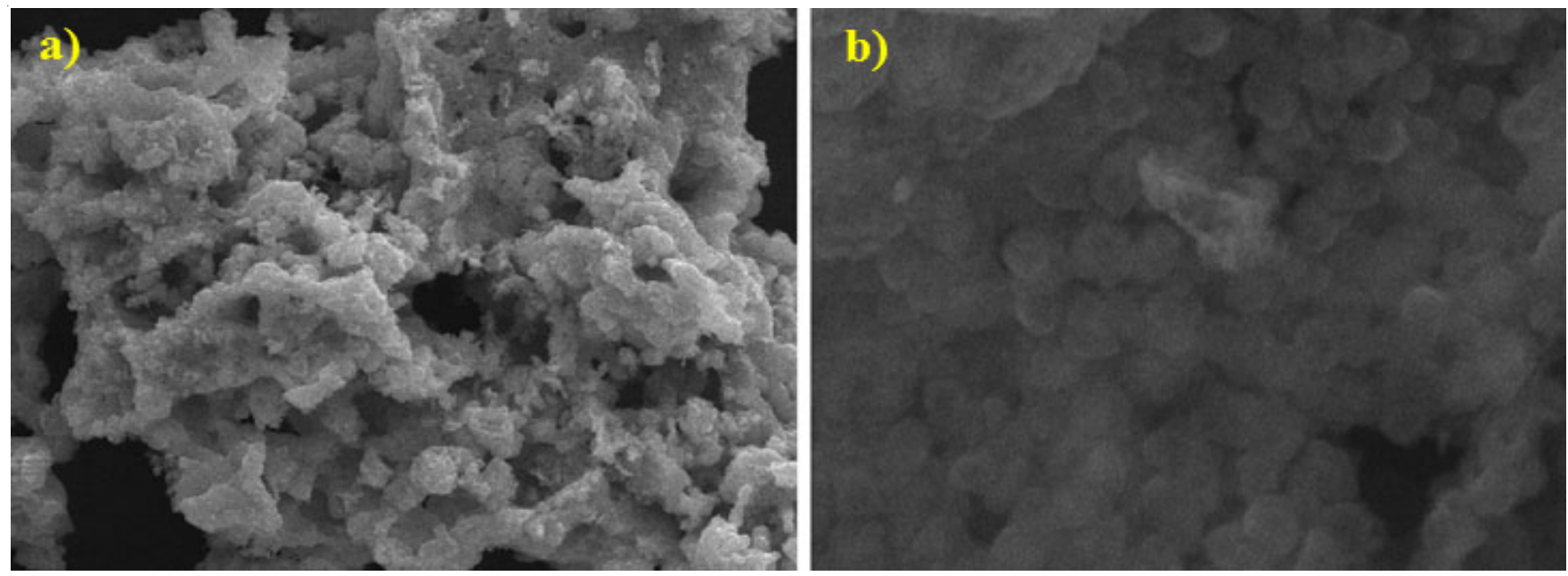

Fig. 5. (a,b) SEM images of green synthesized $\mathrm{CuO}$ nanoparticles from Brassia actinophylla flower extract
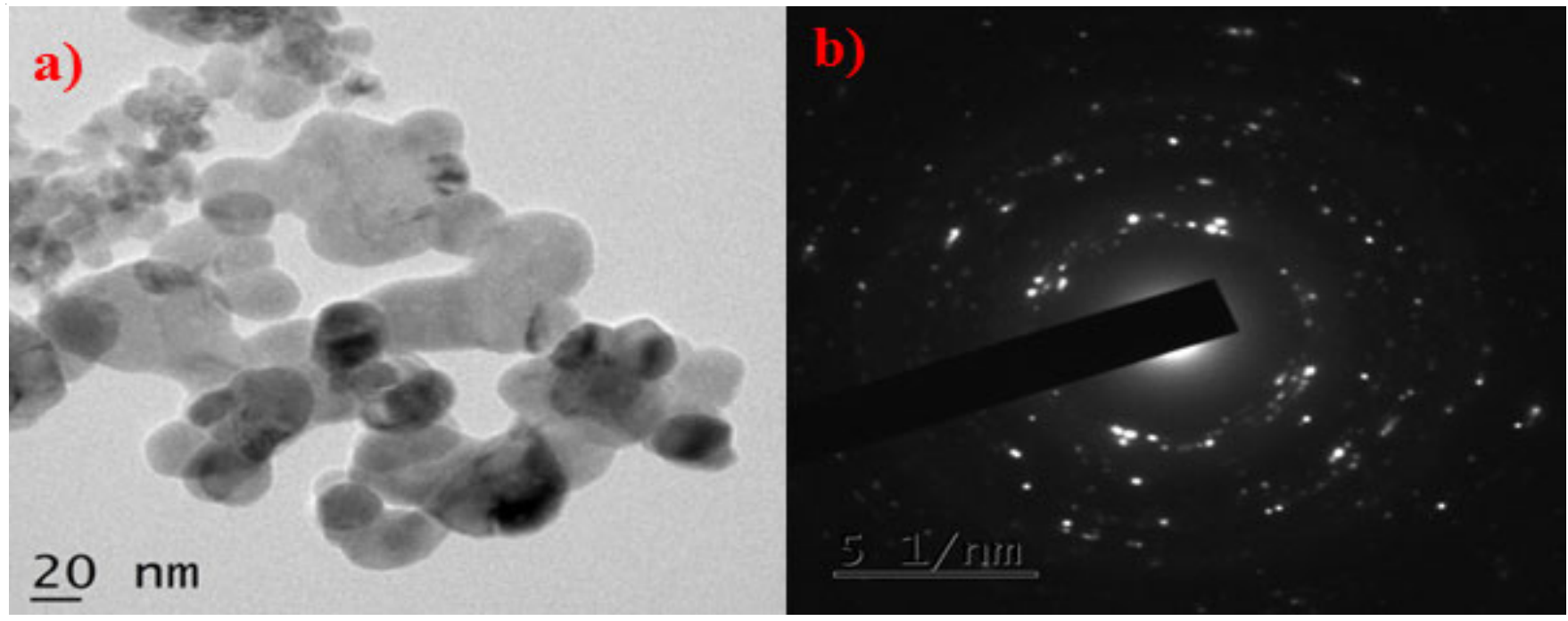

Fig. 6. (a,b) TEM analysis of $\mathrm{CuO}$ nanoparticles from Brassia actinophylla flower extract 


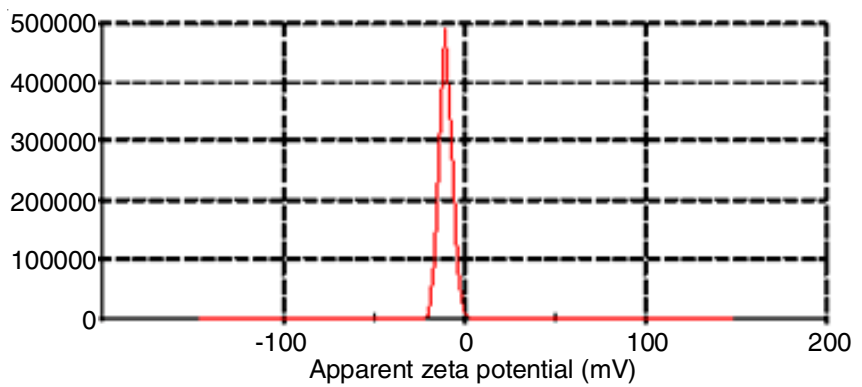

Fig. 7. Zeta potential analysis of $\mathrm{CuO}$ nanoparticles synthesized from Brassia actinophylla flower extract

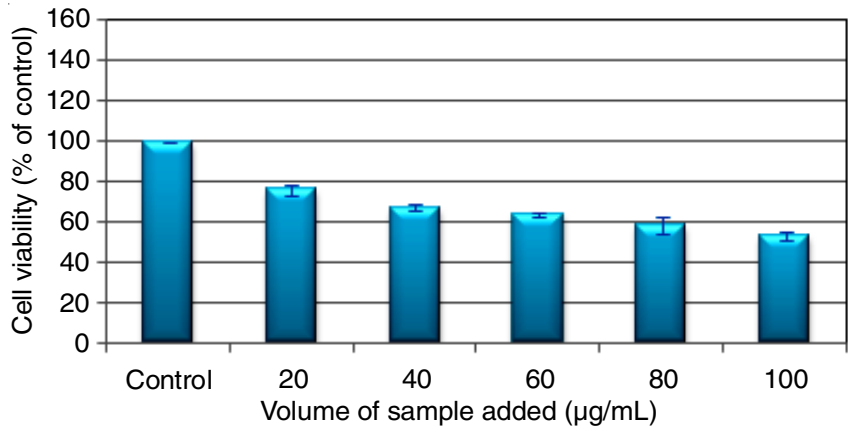

Fig. 8. MTT assay graph for anticancer activity of green synthesized $\mathrm{CuO}$ nanoparticles from Brassia actinophylla flower extract

tage of cell viability was calculated from OD value of MTT assay (Table-1). The synthesized $\mathrm{CuO}$ nanoparticles have revealed poor cytotoxic effect on the colon cancer cell line at initial concentration $(20 \mu \mathrm{g} / \mathrm{mL})$ shows $80 \%$ cell viability. Subsequently increasing the concentration of green synthesized $\mathrm{CuO}$ nanoparticles the viability of cancer cell decreased. At higher concentration of $\mathrm{CuO}$ nanoparticles $(100 \mu \mathrm{g} / \mathrm{mL})$ exhibits 53 $\%$ of cell viability, which proved the synthesized nanoparticles consist potent anticancer activity against colon cancer.

TABLE-1

ANTICACER ACTIVITY REPORT OF CuO NANOPARTICLES SYNTHESIZED FROM Brassia actinophylla FLOWER EXTRACT

\begin{tabular}{cc|cc}
\hline $\begin{array}{c}\text { Concentration } \\
\text { of } \mathrm{CuO} \text { NPs } \\
(\mu \mathrm{g} / \mathrm{mL})\end{array}$ & $\begin{array}{c}\text { Cell viability } \\
(\%)\end{array}$ & $\begin{array}{c}\text { Concentration } \\
\text { of } \mathrm{CuO} \text { NPs } \\
(\mu \mathrm{g} / \mathrm{mL})\end{array}$ & $\begin{array}{c}\text { Cell viability } \\
(\%)\end{array}$ \\
\hline 0 & 100 & 60 & 64 \\
20 & 80 & 80 & 58 \\
40 & 67 & 100 & 53 \\
\hline
\end{tabular}

While synthesizing the metal nanoparticles using plant extract which enhace their biological activity because biological effective compounds of plant are significantly load on its surface. Anticancer efficiency of green synthesized $\mathrm{CuO}$ nanoparticles has been studied for breast cancer (MCF-7), cervical cancer (HeLa), epithelioma (Hep-2) and lung cancer (A549) [46]. The anticancer activity of Brassia actinophylla flower aqueous extract mediated green synthesized $\mathrm{CuO}$ nanoparticles $(100 \mu \mathrm{g} / \mathrm{mL})$ has moderate activity against to colon cancer cell proliferation.

Antibacterial activity: Antibacterial activity of Brassia actinophylla flower extract mediated green synthesized $\mathrm{CuO}$ nanoparticles also examined to evaluate its antimicrobiological application. The green synthesized $\mathrm{CuO}$ nanoparticles were explored against human pathogenic bacteria's such as Staphylococcus aureus (Gram +ve) and Escherichia coli (Gram -ve). The least antibacterial activity was observed at lower concentration exhibits zone of inhibition about $12 \mathrm{~mm}$. Moreover, increasing the concentration of $\mathrm{CuO}$ nanoparticles has revealed higher activity against both gram positive bacteria and gram negative bacteria and simultaneously the highest zone of inhibition was observed by the control drug tetracycline for both organisms ( 33 and $30 \mathrm{~mm}$ ). Although green synthesized $\mathrm{CuO}$ nanoparticles exposed the higher zone of inhibition at 900 $\mu \mathrm{g} / \mathrm{mL}$ concentration for both organisms. Table- 2 shows the green synthesized $\mathrm{CuO}$ nanoparticles has potent antibacterial activity against Staphylococcus aureus than Escherichia coli. Brassia actinophylla flower has abundance of carboxyl groups [47] on cell surface and high affinity of copper toward these carboxyl groups [48]. Thus $\mathrm{CuO}$ nanoparticles have revealed potent antibacterial activity against gram positive bacteria than gram negative bacteria. Spherical shape of nanoparticles and size in the range 2 to $20 \mathrm{~nm}$ could increase the biological activity.

TABLE-2

ANTIBACTERIAL ACTIVITY OF GREEN SYNTHESIZED CuO NPs USING Brassia actinophylla FLOWER EXTRACT

\begin{tabular}{lccc}
\hline \multirow{2}{*}{ Microorganism } & $\begin{array}{c}\text { Conc. } \\
(\mu \mathrm{g} / \mathrm{mL})\end{array}$ & \multicolumn{2}{c}{ Zone of inhibition $(\mathrm{mm})$} \\
\cline { 2 - 3 } & 300 & 12 & Control* \\
\hline \multirow{3}{*}{ Staphylococcus } & 450 & 14 & \\
aureus & 600 & 17 & 33 \\
& 750 & 17 & \\
\hline & 900 & 19 & \\
Escherichia & 300 & 12 & 30 \\
coli & 450 & 14 & \\
& 600 & 15 & \\
\hline
\end{tabular}

*Control: Tetracycline $(300 \mu \mathrm{g} / \mathrm{mL})$

From the above results, it is clear that the antibacterial activity of both Gram +ve and Gram -ve bacteria's are above $9 \mathrm{~mm}$ (zone of inhibition) so the antibacterial activity of $\mathrm{CuO}$ nanoparticles are good in Brassia actinophylla flower extract compared to Rauvolfia serpentine [35]. The cell viability of $\mathrm{CuO}$ nanoparticles at the concentration of $20 \mu \mathrm{g} / \mathrm{mL}$ observed was $80 \%$. It shows that at lesser concentration, anticancer activity of $\mathrm{CuO}$ nanoparticles synthesized from Brassia actinophylla flower are high [46].

\section{Conclusion}

The synthesis of $\mathrm{CuO}$ nanoparticles using Brassia actinophylla flower extract has been carried out successfully by solution combustion method. The combustion was done at three different temperatures and $\mathrm{CuO}$ nanoparticles were achieved at $400{ }^{\circ} \mathrm{C}$. The biosynthesized $\mathrm{CuO}$ nanoparticles were confirmed by UV-visible and FT-IR spectrum studies, which clearly indicates the biomolecules present in Brassia actinophylla flower potentially reduce the metal ions into metal nanoparticles and also act as green stabilizing agent. Powder XRD pattern confimed the monoclinic cyrstalline nature of synthesized $\mathrm{CuO}$ nanoparticles. The morphological analysis of $\mathrm{CuO}$ nanoparticles acertained through SEM images, displayed the particles are free agglomeratd with spherical in shape. TEM images of $\mathrm{CuO}$ nanoparticles revealed that size of nanoparticle 
is in the range of 2 to $20 \mathrm{~nm}$. Zeta potential analysis ensures that the synthesized $\mathrm{CuO}$ nanoparticles by green method are moderately stable. The significant anticancer activity of nanoparticles for colon cancer and antibacterial activity against selected pathogenic bacteria are supports to estabilish the biological and pharmaceautical applications of green synthesized $\mathrm{CuO}$ nanoparticles.

\section{CONFLICT OF INTEREST}

The authors declare that there is no conflict of interests regarding the publication of this article.

\section{REFERENCES}

1. J. Liu, S.Z. Qiao, Q.H. Hu and G.Q. Lu, Small, 7, 425 (2011); https://doi.org/10.1002/sml1.201001402.

2. N.A. Luechinger, R.N. Grass, E.K. Athanassiou and W.J. Stark, Chem. Mater, 22, 155 (2010); https://doi.org/10.1021/cm902527n.

3. P. Mohanpuria, N.K. Rana and S.K. Yadav, J. Nanopart. Res., 10, 507 (2008);

https://doi.org/10.1007/s11051-007-9275-x.

4. S. Honary, H. Barabadi and E. Gharaei-Fathabad, J. Nanomater. Biostruct., 10, 999 (2012).

5. I. Capek, Adv. Colloid Interface Sci., 110, 49 (2004); https://doi.org/10.1016/j.cis.2004.02.003.

6. B.S. Yin, H.Y. Ma, Y. Wang and S. Chen, J. Phys. Chem. B, 107, 8898 (2003); https://doi.org/10.1021/jp0349031.

7. S.B. Patil, T.N. Ravishankar, K. Lingaraju, G.K. Raghu and G. Nagaraju, J. Mater. Sci. Mater. Electron., 29, 277 (2018); https://doi.org/10.1007/s10854-017-7914-2.

8. V. Helan, J.J. Prince, N.A. Al-Dhabi, M.V. Arasu, A. Ayeshamariam, G. Madhumitha, S.M. Roopan and M. Jayachandran, Results in Physics, 6, 712 (2016); https://doi.org/10.1016/j.rinp.2016.10.005.

9. P. Yugandhar, R. Haribabu and N. Savthramma, 3 Biotech., 5, 1031 (2015); https://doi.org/10.1007/s13205-015-0307-4

10. R. Kalyanaraman, S. Yoo, M.S. Krupashankara, T.S. Sudarshan and R.J. Dowding, Nanostruct. Mater., 10, 1379 (1998); https://doi.org/10.1016/S0965-9773(99)00017-3.

11. A. Umer, S. Naveed and N. Ramzan, Nano: Brief Rep. Rev., 7, 1230005 (2012); https://doi.org/10.1142/S1793292012300058.

12. S.S. Shankar, A. Rai, A. Ahmad and M. Sastry, J. Colloid Interface Sci., 275, 496 (2004); https://doi.org/10.1016/j.jcis.2004.03.003.

13. J. Huang, Q. Li, D. Sun, Y. Lu, Y. Su, X. Yang, H. Wang, Y. Wang, W. Shao, N. He, J. Hong, C. Chen, Nanotechnology, 18, 105104 (2007); https://doi.org/10.1088/0957-4484/18/10/105104.

14. S.S. Shankar, A. Rai, B. Ankamwar, A. Singh, A. Ahmad and M. Sastry, Nat. Mater., 3, 482 (2004); https://doi.org/10.1038/nmat1152.

15. B. Ankamwar, M. Chaudhary and M. Sastry, Nano-Metal Chem., 35, 19 (2005); https://doi.org/10.1081/SIM-200047527.

16. B.S. Ravikumar, H. Nagabhushana, D.V. Sunitha, S.C. Sharma, B.M. Nagabhushana and C. Shivakumara, J. Alloys Compd., 585, 561 (2014); https://doi.org/10.1016/j.jallcom.2013.09.080.

17. S. Yang, C. Wang, L. Chen and S. Chen, Mater. Chem. Phys., 120, 296 (2010); https://doi.org/10.1016/j.matchemphys.2009.11.005.

18. P. Podhajecky, B. Klapste, P. Novak, J. Mrha, R. Moshtev, V. Manev and A. Nassalevska, J. Power Sources, 14, 269 (1985); https://doi.org/10.1016/0378-7753(85)80042-2.

19. T. Yu, F.C. Cheong and C.H. Sow, Nanotechnology, 15, 1732 (2004); https://doi.org/10.1088/0957-4484/15/12/005.

20. S.K. Yip and J.A. Sauls, Phys. Rev. Lett., 69, 2264 (1992); https://doi.org/10.1103/PhysRevLett.69.2264.
21. M.S. Tokumoto, V. Briois, C.V. Santilli and S.H. Pulcinelli, J. Sol-Gel Sci. Technol., 26, 547 (2003); https://doi.org/10.1023/A:1020711702332.

22. P. Kumar, L.S. Panchakarla, S. Venkataprasad Bhat, U. Maitra, K.S. Subrahmanyam and C.N.R. Rao, Nanotechnology, 21, 385701 (2010); https://doi.org/10.1088/0957-4484/21/38/385701.

23. G. Thomas, Nature, 389, 907 (1997); https://doi.org/10.1038/39999.

24. C.H. Xu, C.H. Woo and S.Q. Shi, Chem. Phys. Lett., 399, 62 (2004); https://doi.org/10.1016/j.cplett.2004.10.005.

25. R. Sankar, R. Dhivya, K.S. Shivashangari and V. Ravikumar, J. Mater. Sci. Mater. Med., 25, 1701 (2014); https://doi.org/10.1007/s10856-014-5193-5.

26. R. Sankar, A. Karthik, A. Prabu, S. Karthik, K.S. Shivashangari and V. Ravikumar, Colloids Surf. B Biointerfaces, 108, 80 (2013); https://doi.org/10.1016/j.colsurfb.2013.02.033.

27. S. BarathManiKanth, K. Kalishwaralal, M. Sriram, S.B. Pandian, H. Youn, S.H. Eom and S. Gurunathan, J. Nanobiotechnology, 8, 16 (2010); https://doi.org/10.1186/1477-3155-8-16.

28. J. Beasely, Plants of Tropical North Queensland: The Compact Guide, Footloose Publications: Kuranda, Australia, pp. 192 (2006).

29. E. Frankel, Nutritional Benefits of Flavnoids, Proceedings of the International Conference of Food Factors: Chemistry and Cancer Prevention, Hamamastu, Japan, December 10-15,(1995).

30. H. Wang, J.-Z. Xu, J.-J. Zhu and H.-Y. Chen, J. Cryst. Growth, 244, 88 (2002); https://doi.org/10.1016/S0022-0248(02)01571-3.

31. C.K. Xu, Y.K. Liu, G.D. Xu and G.H. Wang, Mater. Res. Bull., 37, 2365 (2002); https://doi.org/10.1016/S0025-5408(02)00848-6.

32. Q. Zhang, Y. Li, D. Xu and Z. Gu, J. Mater. Sci. Lett., 20, 925 (2001); https://doi.org/10.1023/A:1010984917974.

33. H. Fan, L. Yang, W. Hua, X. Wu, Z. Wu, S. Xie and B. Zou, Nanotechnology, 15, 37 (2004); https://doi.org/10.1088/0957-4484/15/1/007.

34. M. Chandrasekhar, H. Nagabhushana, S.C. Sharma, K.H. Sudheer Kumar, N. Dhananjaya, D.V. Sunitha, C. Shivakumara and B.M. Nagabhushana, J. Alloys Compd., 584, 417 (2014); https://doi.org/10.1016/j.jallcom.2013.08.149.

35. K. Lingaraju, H.R. Naika, K. Manjunath, G. Nagaraju, D. Suresh and H. Nagabhushana, Acta Metall. Engl. Lett., 28, 1134 (2015); https://doi.org/10.1007/s40195-015-0304-y.

36. J. Zhou, S. McClean, A. Thompson, Y. Zhang, C. Shaw, P. Rao and A.J. Bjourson, Peptides, 27, 3077 (2006); https://doi.org/10.1016/j.peptides.2006.08.007.

37. L.J. Gong and S.X. Guo, Afr. J. Biotechnol., 8, 731 (2009).

38. M.V. Berridge, P.M. Herst and A.S. Tan, Biotechnol. Annu. Rev., 11, 127 (2005); https://doi.org/10.1016/S1387-2656(05)11004-7.

39. M. Ilamathi, S. Santhosh and V. Sivaramakrishnan, Curr. Top. Med. Chem., 16, 2453 (2016); https://doi.org/10.2174/1568026616666160212122820.

40. D. Das, B.C. Nath, P. Phukon and S.K. Dolui, J. Colloids Surf. B Biointerfaces, 101, 430 (2013); https://doi.org/10.1016/j.colsurfb.2012.07.002.

41. D.P. Dubal, G.S. Gund, C.D. Lokhande and R. Holze, Mater. Res. Bull., 48, 923 (2013); https://doi.org/10.1016/j.materresbull.2012.11.081.

42. Z. Fereshteh, M. Salavati-Niasari, K. Saberyan, S.M. Hosseinpour-Mashkani and F. Tavakoli, J. Cluster Sci., 23, 577 (2012); https://doi.org/10.1007/s10876-012-0477-8.

43. H.R. Naika, K. Lingaraju, K. Manjunath, D. Kumar, G. Nagaraju, D. Suresh and H. Nagabhushana, J. Taibah Univ. Sci., 9, 7 (2015); https://doi.org/10.1016/j.jtusci.2014.04.006.

44. P.C. Nagajyothi, P. Muthuraman, T.V.M. Sreekanth, D.H. Kim and J. Shim, Arab. J. Chem., 10, 215 (2017); https://doi.org/10.1016/j.arabjc.2016.01.011.

45. S. Bhattacharjee, J. Control. Rel., 235, 337 (2016); https://doi.org/10.1016/j.jconrel.2016.06.017.

46. D. Rehana, D. Mahendiran, R.S. Kumar, A.K. Rahiman, Biomed. Pharmacother, 89, 1067 (2017); https://doi.org/10.1016/j.biopha.2017.02.101.

47. T.J. Beveridge and R.G. Murray, J. Bacteriol., 141, 876 (1980).

48. R.J. Doyle, T.H. Matthews and U.N. Streips, J. Bacteriol., 143, 471 (1980). 